\title{
Defying Dehumanization by Sending Books: A Brief History of Books Through Bars NYC
}

\author{
I just received your book WEB Dubois and its is a buitful $<$ sic $>$ book he \\ tell it like it is and let us brothers are Afro-American know where all our \\ struggle derives from. \\ - Person incarcerated in Texas
}

Books Through Bars NYC (New York City) was started in 1996 as a joint project of Blackout Books (a NYC anarchist bookstore) and the Nightcrawlers chapter of the Anarchist Black Cross (a prison abolition group that supports political and politicized people in prison). The allvolunteer group was founded specifically to send free books about politics and radical history to people in prison.

As people who believe in the power of the written word to transform people's worldview and lives, we wanted to ensure that prisoners were able to receive books that pushed them to think past their immediate experiences and to begin examining the role of systemic oppressions in their lives. We also realized that such books were least likely to be in their prison libraries.

Why are books and educational literature important in prisons? Studies have shown that people in prison are those who are least likely to have access to educational opportunities. Schools in poor communities, particularly poor communities of colour, increasingly focus on policing and punishing students. More and more, these schools resemble prisons, complete with metal detectors and uniformed law enforcement, pushing children out of the school system and into the juvenile justice system. Students of colour are disproportionately singled out for punishment more than their white peers. Many of the people who end up in prison had little access to meaningful educational opportunities before incarceration (Brown, 2003).

I am presently trying to learn to read and write and to develop my small artistic skills. My reading level is around grade three. Any literature you could provide me in either of these fields would be greatly appreciated. Thanks.

- Frank in Tennessee

P.S. My name is Warren and I am locked-up with Frank. I wrote this letter for him and can testify that he is striving hard to improve his life skills. 
A 2003 report by the Bureau of Justice Statistics (Harlow, 2003) found that:

- 42 percent of women and 40 percent of men in prison had neither high school diplomas nor GEDS;

- Only 36 percent of women and 32 percent of men had graduated from high school; and

- Even fewer people had attended any sort of postsecondary institution before incarceration.

Until 1994, people in prison were eligible for Pell grants, which funded over 300 college-in-prison programs across the United States. Although Pell grants to prisons took up less than 1 percent of the annual Pell grant budget, Congress cut Pell grants to prison education programs in 1994. In the following years, the number of college-in-prison programs across the nation dropped from 350 to less than a dozen. In 1995, New York State cut TAP (Tuition Assistance Program) grants to people in prison, a move that resulted in the closure of most of the state's 70 college education programs in prison.

In addition, nowhere is it legally mandated that prisoners have a right to educational or recreational reading material, including through general library services. Thus, access to books in prison varies from state to state.

This was the atmosphere in which Books Through Bars NYC started. Since then, the group has expanded its selection to send a wider range of material, including fiction (especially fiction by authors of colour), history, poetry, how-to books, thesauruses and dictionaries. During the last sixteen years, the group has received thousands of letters from people in state and federal prisons in all fifty states and sent free books, magazines and photocopied information in response to their requests. We currently receive over 400 book request letters per month from people in prison and send out almost as many book packages in response.

Books Through Bars NYC remains an all-volunteer group. Current volunteers hold different beliefs about the American prison system - some are abolitionists while others are pro-prison-reform. But all of us are startled and angered by how difficult it is (see Dexheimer, 2010) for prisoners to access decent educational reading material on the inside. All of us believe that literacy and access to reading material is a human right. 
We hold packing sessions three times a week; during these sessions, volunteers - both old and new - come together for a few hours to read letters from people in prison, search for books on the subjects requested and prepare them for mailing. All of the books have been donated by individuals and publishers who share our belief that prisoners have a right to read. The group's workspace is in the basement of a local bookstore called Freebird Books, which has generously donated its use. The group's only operating expense is the ever-increasing cost of postage.

Volunteers help fundraise to cover postage costs in a variety of ways: we hold benefit fundraisers, such as film screenings, music shows, and an annual Bingo event. Individuals who support the group's mission have also donated funds. For the past five years, Books Through Bars has received a grant from the Sonya Staff Foundation, a small family foundation that covers several months of postage costs.

Some of our fundraisers also serve as educational events: In February 2011, Books Through Bars teamed up with artist collective JustSeeds to hold a silent art auction featuring their prison portfolio. The event garnered much-needed postage money and highlighted the numerous realities of incarceration to those in the visual arts community. Later that year, we hosted a performance of In the Belly, a play about long-term solitary confinement by the traveling performance troupe Insurgent Theater. After the performance, Books Through Bars and Insurgent Theater members held a discussion about the contents of the play and the reality surrounding people in long-term solitary confinement in the United States.

We understand that sending books to people in prison does not appreciably change the dehumanizing, exploitative prison system. However, for many in prison, programs like ours are their only source of reading material and so, whether we are reformers or abolitionists, we engage in an act with implications that are both humane and personally liberatory.

I got the set of 4 books today. I already have a list of who got the books next. I do thank you very much for the books and I know the other guys like them also. 


\section{REFERENCES}

Browne, Judith A. (2003) Derailed: The Schoolhouse to Jailhouse Track, Washington (D.C.): Advancement Project. Retrieved from <http://www.advancementproject.org/ sites/default/files/publications/Derailerepcor0.pdf>

Dexheimer, Eric (2010) "Banned in Texas prisons: books and magazines that many would consider classics", American Statesman - March 19. Retrieved from < http:// www.statesman.com/news/news/state-regional-govt-politics/banned-in-texasprisons-books-and-magazines-that-m/nRh7w/>.

Wolf Harlow, Caroline (2003) Educational and Correctional Populations, Special Report to the Department of Justice.

\section{ABOUT THE AUTHOR}

Victoria Law is one of the co-founders of Books Through Bars NYC. She is also a writer, photographer, mother and prison abolitionist. She is the author of Resistance Behind Bars: The Struggles of Incarcerated Women and the co-editor of the zine Tenacious: Art and Writings from Women in Prison. She can be reached at vikkimL@yahoo.com. 